\title{
Pre-Election Mobilization and Electoral Outcome in Authoritarian Regimes
}

\author{
Mohammad Ali Kadivar \\ Watson Institute for International and Public Affairs \\ Brown University \\ Gorman, Charles Kurzman, Charlotte Lloyd, Yonatan Morse, Graeme Robertson, Charles
}

For their comments and suggestions, I thank Shawn Bauldry, Shane Elliott, Brandon Seguin, the editor and anonymous reviewers at Mobilization.

Accepted for Publication at

Mobilization: An International Quarterly 


\title{
Pre-Election Mobilization and Electoral Outcome in Authoritarian Regimes
}

\begin{abstract}
Does pre-election protest have an effect on the outcomes of authoritarian elections? Electoral authoritarian regimes use elections to consolidate their power and claim democratic legitimacy. Nonetheless, on some occasions authoritarian incumbents lose elections despite their advantages and a democratic breakthrough is achieved. I propose that pre-election protest contributes to such election results. Existing scholarship focuses primarily on the effectiveness of post-election upheavals, but the effects of pre-election protest are still theoretically and empirically understudied. This paper proposes a theory for why pre-election contention has an independent effect on incumbent defeat of authoritarian regimes and democratization. I present empirical support for the association between pre-election protest activities, incumbent defeat, and democratization using data from 190 elections across 65 countries with non-democratic regimes. The findings of this analysis have important implications for studies of social movements, authoritarian politics, and democratization.
\end{abstract}




\section{Pre-Election Mobilization and Electoral Outcome in Authoritarian Regimes}

While elections are central to democracy, holding elections is not sufficient for a regime to be considered democratic. Most authoritarian regimes in the world hold elections in which the incumbents are almost always assured of victory due to abuse of power, violation of civil liberties, and electoral manipulation. Nonetheless, on rare occasions oppositions can defeat an authoritarian incumbent and achieve a democratic breakthrough. Does pre-election protest contribute to such electoral outcomes? While many studies consider opposition mobilization only weakly related to political change in electoral authoritarian regimes (Levitsky and Way 2010), others document the positive effects of protest mobilization on democratizing outcomes in such cases (Howard and Roessler 2006). I side with the scholarship favoring the effectiveness of electoral protest for democratic outcomes. Among these studies, the effects of post-election protests are well documented but pre-election protest has not received adequate theoretical and empirical attention. In this paper, I focus on pre-election protest and, building on existing studies of democratization and contentious politics (Fallon, Swiss, and Viterna 2012; Haggard and Kaufman 2012; Schock 2005), I present a theoretical framework that illustrates why pre-election protest increases the likelihood of an incumbent defeat and democratic breakthrough following an election held under conditions of authoritarianism.

This paper's empirical examination and theoretical framework address important gaps within the social movements literature. First, although scholars have developed rigorous research programs to investigate elections (Lijphart 2012; Norris 2004) and social movements (McAdam, Tarrow, and Tilly 2001; Snow, Soule, and Kriesi 2008) as major manifestations of politics in the modern era, only a few studies have considered the 
relationship of these two important political phenomena (Amenta 2006; Andrews 2004; Goldstone 2003). In a recent reflection on this surprising disengagement, McAdam and Tarrow (2010:532) wrote that "the relations between social movements and elections have seldom been specified in a systematic way that could set us on the road to predicting how movements affect elections and vice versa." To fill this gap, McAdam and Tarrow specified six mechanisms that connect social movement actors to routine political actors. This paper elaborates on and tests one of these mechanisms: popular mobilization before elections.

Democratization is one of the more significant consequences of popular mobilizations that has been understudied from the perspective of political process theory, the dominant approach of social movement studies (Tarrow 2012:21). The literature on the consequences of social movements, for instance, has mostly focused on the outcome of policy change since it studies the outcome of movements in the context of consolidated democracies (Amenta et al. 2010; Giugni 1998). To fill this gap, this paper builds on the general social movements scholarship and the few existing studies of movements in authoritarian states (Almeida 2003; Goodwin 2001; Wood 2000) in order to theorize the ability for contentious collective action to empower opposition groups and thus affect electoral outcomes in authoritarian regimes. Pre-election protest has an independent effect on electoral outcomes because it shows there are viable alternatives to the regime, encourages defection within the regime, signals the spread of grievances to both the regime and voters, and sometimes create new grievances when faced with repression. I present empirical support for the effectiveness of pre-election contention by analyzing a dataset of 190 elections in 65 countries with electoral authoritarian regimes 
from 1990 to 2004. My findings indicate an association between pre-election mobilization and incumbent defeat as well as between pre-election mobilization and democratization in the election. In what follows, I first introduce the concept of electoral authoritarianism, which specifies the universe of my cases. Then, I review the few existing studies that consider the impact of electoral contention on democratization in authoritarian elections. Next, I introduce my theory about the empowering effects of preelection mobilization for the opposition. Finally, I introduce the data and test hypotheses derived from my theory against rival explanations for democratization in electoral authoritarian regimes.

\section{Authoritarian Elections, Mobilization, and Democratization}

Electoral authoritarianism is now the most common form of authoritarian rule in the world as there are very few non-democratic governments that do not hold national elections (e.g. Saudi Arabia, North Korea, Cuba, China). Electoral authoritarian regimes claim democratic legitimacy on the basis of regularly held elections. However, these elections are either formally limited to roles that would prevent a complete power rotation or, when authorized to change executive power on paper, they fall short of the conditions necessary for free and fair elections. Incumbents in these regimes abuse public institutions to advantage the playing field in favor of the ruling party, violate civil liberties, and manipulate the election process to guarantee their electoral victory (Diamond 2002; Levitsky and Way 2002; Schedler 2006). Accordingly, some scholars argue that incumbent leaders use these elections to consolidate their power (Blaydes 2010; Lust-Okar 2006; Magaloni 2008). 
Even though incumbents enjoy considerable advantages in these elections, on some occasions they lose the electoral battle to the opposition (e.g. Kenya 2002). In authoritarian elections, incumbents stand as the main obstacle to the democratic rotation of executive power in the eyes of the opposition. Thus, when incumbents lose and executive power is rotated to the opposition, a democratic breakthrough can be achieved. A democratic breakthrough could also occur without incumbent defeat in cases where incumbents hold fair and free elections and win (e.g. Ghana 1996). Under what conditions, then, does a democratic breakthrough of either sort occur?

To address this puzzle, scholars point to various factors such as the degree of competitiveness within the regime (Brownlee 2009a; Roessler and Howard 2009), linkage with democratic superpowers (Levitsky and Way 2010), international pressure on the fairness of elections (Donno 2013), features of the information environment (PopEleches and Robertson 2015), regime strategies such as fraud and harassment of the opposition, and opposition strategies such as coalition building (Bunce and Wolchik 2011; Donno 2013; Howard and Roessler 2006). I propose that pre-election protest also contributes to incumbent defeat and democratization. In this paper I adopt a minimal definition of democracy as a set of procedures and institutions through which citizens can effectively express their preferences about alternative policies and leaders, and institutionalized constraints on the exercise of executive power (Marshall, Gurr, and Jaggers 2011). Any improvements in the direction of establishing and consolidating these procedures and institutions would be considered democratization (for a similar approach see Wejnert 2005). 
The effectiveness of mass mobilization for election outcomes in authoritarian regimes has been the subject of scholarly debates. One strand of classic studies of democratic transitions was pessimistic about the effectiveness of mass mobilization for democratization, arguing that contention is either detrimental to the transition process or ephemeral (Huntington 1984; O’Donnell and Schmitter 1986). This pessimism has been echoed in contemporary research on the outcome of authoritarian elections. These studies emphasize that, rather than opposition mobilization, it is the features of the incumbent regime itself, such as coercive capacity or degree of competitiveness, which determine their trajectories. Levitsky and Way offer a metaphor to explain this theoretical approach:

Consider the story of the three little pigs. Setting normative preferences aside, imagine that the pigs are autocratic incumbents, their houses are their regimes, and the wolf represents prodemocracy movements. The wolf huffs and puffs at all three houses, but the impact of his huffing and puffing varies across cases: Whereas the houses of straw and sticks quickly collapse, the house of bricks remains intact. The key to explaining these outcomes lies not in the wolf 's abilities or strategies but in differences in the strength of the houses (2010:54).

In contrast to this regime-centered approach, there are studies that explore the effects of opposition mobilization on incumbent defeat and democratization, with postelection protest receiving the lion's share of attention. Scholars in this area have empirically demonstrated that voters who are outraged about fraudulent elections and aware of the similar feelings of fellow voters turn to the streets to protest stolen elections. These uprisings can sometimes force the regime to withdraw and accept the election's real winners (e.g. Serbia 2000, Ukraine 2004). This model of electoral revolution has been adopted by a wide range of activists around the world as a plausible strategy for creating regime change (Beissinger 2007; Bunce and Wolchik 2011; Tucker 2007). 
There are also a few studies of pre-election mobilization and its impact on electoral outcomes. Bunce and Wolchik (2011) in their important analysis of incumbent defeat in authoritarian elections in Eastern and Central Europe argue that pre-election tactics and strategic choices by the opposition offer the best explanation for the variation in election outcomes. "Forming a united front among opposition parties, forging close alliances between the opposition and civil society groups, and carrying out ambitious nationwide campaigns and voter registration and turnout drives" are among the most effective tactics deployed by the opposition (Bunce and Wolchik 2011:33). Although this analysis presents some informative insights about protest tactics, the focus of the argument is on electoral tactics rather than contentious collective action.

There are also a few studies that pay specific attention to contentious collective action undertaken by the opposition (Howard and Roessler 2006; Schedler 2009, 2013). While these studies find a positive impact for opposition mobilization on democratization in elections, they suffer from limitations in terms of conceptualizing mass mobilization as well as measuring protest. First, these studies' concept of protest focuses exclusively on protests organized by the established opposition parties. This formulation excludes a variety of protest actions that could affect the incumbents' power to control the election. I argue for the expansion of protest events to include those led by any number of social groups because, regardless of the organizing entity, pre-election protests can fundamentally affect the political strategies of regime incumbents, formal opposition groups, and voters. In contrast to a limited conceptualization of protest, this broader conceptualization of protests does not require specific demands about the election to affect the election outcome. Instead, demands for democratization often emerge from 
escalating protests that expand to include many social groups. The wave of protests in Tunisia during 2010-2011 is a recent example of how protests can take on a life of their own. Protest demands initially addressed only unemployment and poverty, but escalated over the course of a few weeks to include the condemnation of repression and, finally, the resignation of the standing president Ben Ali to make way for free elections. In Tunisia, political parties were among the last to join the revolt while neighborhood youth and teachers unions played an active role in organizing protest events from the beginning (Hmed 2012; Saidani 2012).

The second limitation of previous scholarship stems from the way the concept of protest is operationalized. Howard and Roessler's (2006) study, for instance, uses data from the Cross-National Time-Series (Banks and Wilson 2013), which is based on coding of the average counts of demonstrations for the election year and the previous year in New York Times news articles. This approach is limited in three ways. First, this method conflates pre- and post-election protests, which does not allow for their differential effects on liberalizing outcomes to be disentangled. Second, a liberalizing outcome in an election may function as a political opportunity for contenders and increase the intensity of post-election protests, making causal inferences about the effect of protests on the election outcome drawn from these data dubious. Third, the use of New York Times articles as a comprehensive database of protest events is limited: the Times does not have bureaus in all countries, it provides uneven coverage of political events in different regions, and its coverage is likely biased towards reporting liberalizing outcomes. To address this issue, I use a daily measure of protest that allows us to distinguish preelection contention from post-election mobilization. 


\section{Pre-election Protest and Opposition Empowerment}

Pre-election contentious collective action may lead to democratization through incumbent defeat for several different reasons. This paper defines contentious collective action as collective events that represent subversive acts such as protesting demonstrating or rioting versus methods of conventional politics such as voting and lobbying that challenge normalized practices and existing systems of authority (Beissinger 2002; Tilly and Tarrow 2007). Contention might force the government to make concessions in terms of more competitive elections, encourage defection within the regime, or motivate voters to cast ballots for the opposition by signaling the spread of grievances and raising the level of grievances. This theoretical framework is similar to what Giugni (2007) calls an indirect-effect model, according to which protest makes a difference by influencing a certain aspect of the external environment-in this case incumbent defeat-and then subsequently affecting the major outcome of interest-in this case democratization.

Pre-election protests send signals to the regime, opposition, and voters about the viability of an alternative for the regime, challenge the myth of regime omnipotence, and increase the range and intensity of grievances (Kurzman 2004). First, incumbent leaders realize they are facing a serious challenge and perhaps revolutionary threats when they witness contentious collective action. They may try to manage such challenges by holding more competitive elections (Acemoglu and Robinson 2005; Boudreau 2009; Wood 2000). Since the government is trying to appease protesters, the regime may be less likely to resort to fraud under these circumstances, allowing the opposition to enjoy a greater chance at victory (Schedler 2013). 
On the other hand, certain elements within the regime or third parties might realize that cooperation with the regime is not the only viable option. Pre-election protest could show that the regime is facing serious challengers. Insiders or third parties might then consider staying neutral or even cooperating with the opposition. Accordingly, popular protests against authoritarian governments on many occasions result in defections from the regime (Boudreau 2009; Chenoweth and Stephan 2012; Schock 2005). Under such conditions the incumbent would face difficulty in collecting the votes required for victory and the opposition enjoys a better chance of receiving electoral support.

During the period of military rule in Brazil, for example, the opposition organized a series of demonstrations in 1984 and demanded the replacement of an electoral college system with direct presidential elections. Although the movement failed to achieve this goal in the short term, it led to an important defection of the official National Alliance Renewal Party to the opposition Brazilian Democratic Movement party. As a result, in the following year the opposition leader Tancredo Neves was indirectly elected as Brazil's president, which was the first time since 1960 that the military's candidate did not win the election (Haggard and Kaufman 1995:73).

Another example is Indonesia, where days of massive protests and rioting in May 1998 forced President Suharto to resign after 31 years of rule. Suharto's New Order was based on the claim that only his government could save the country from chaos. Days of urban rioting thoroughly discredited this foundational claim. Following this tumult, the ruling elite in the dominant Golkar party decided to abandon Suharto and called for his resignation (Aspinall 2005). After Suharto's departure, Vice-president Habibie immediately promised fair and free elections and electoral reform to appease protestors. 
Changes in electoral law stripped the reigning Golkar party of the privileges it had enjoyed for decades (Bird 1999), resulting in the fall of Golkar party in the 1999 presidential election after 33 years in power.

Protest events also signal to the opposition and voters that grievances against the regime are widespread and that there are a considerable number of people willing to defy the status quo. This would matter particularly in the context of authoritarian regimes, since citizens might be unsatisfied with the incumbents but not dare to express their grievances and, accordingly, would be unaware of other citizens sharing their dissatisfaction and desire for political change (Kuran 1995). The option of going to ballot boxes and voting for the opposition, then, would appear a more reasonable option rather than a futile attempt that would only contribute to the legitimacy of a fake election.

Protest events also might raise the level of grievances or redirect them (Oliver 1989). Authoritarian governments usually try to manage their populations' grievances and channel them toward targets other than the regime through tactics such as disseminating pro-regime propaganda, censoring independent media, and monopolizing public discourse. Protest events can effectively challenge the regime's domination of political discourse by highlighting various grievances and blaming the regime for them. In addition, brutal crackdowns on protesters sometimes forge new grievances, escalating mobilization against regimes (Boudreau 2009). While new grievances could fuel further protest, they could also lead to changes in the electoral behavior of the voters. If citizens realize that electoral action could be an effective way to address their dissatisfactions, they are more likely to resort to the ballot boxes. The opposition also could use the new grievances in their electoral campaign against the incumbent regime. 
In Thailand, for example, during the campaign for the September 1992 election, the press focused on the military's bloody crackdown on protestors. A widely used frame portrayed 'angels', opposition parties such as the Democrats that had challenged military rule, versus 'devils', the military leaders and provincial politicians that supported them in their successful election the previous March. Despite this defeat, the Democrats managed to win the September election in a tight race with the military-backed party (Pasuk and Baker 2002). Similarly, in Serbia, the regime's crackdown on the young members of Otpor for their protest activities generated new grievances about the government's cruel tactics in dealing with the opposition. Otpor also used several innovative tactics to bring the brutalities and wrongdoings of Milosevic's regime to the public's attention (Bunce and Wolchik 2011; Meyers 2009).

Since pre-election protest signals the spread of grievances to the voters and opposition, presents the opposition as an alternative option, encourages defection from the ruling elite, and also creates new grievances, we should expect a better chance for incumbent defeat as pre-election protests increase. Thus, I hypothesize that pre-election protest increases the chance of incumbent defeat and, accordingly, democratization.

\section{Data and Method}

This paper analyzes 190 elections in 65 countries with electoral authoritarian regimes from 1990 to 2004. I rely on Roessler and Howard's (2009) conceptualization and measurement of regime type to determine the set of cases in this study: all 65 regimes that received a polity score between -8 and 6 according to Polity IV or a score between 2 and 7 for their political rights from Freedom House. The elections held in these countries 
were then extracted from a comprehensive dataset of elections, National Elections across Democracy and Autocracy (NELDA), which draws on a wide range of primary and secondary sources to provide detailed information for all direct elections in 157 countries from 1946 to 2010 (Hyde and Marinov 2012). NELDA includes 58 variables concerning different aspects of each election such as pre-election polls, the level of reported fraud, violence surrounding the election, limitations on the opposition, the presence of international monitors, and international reactions to the election. ${ }^{1}$ Such detailed information about elections is not included in other major electoral datasets such as that of the International Institute for Democracy and Election Assistance (IDEA). Since some argue that the dynamics of the founding elections differ from regular elections in electoral authoritarianism (Howard and Roessler 2006), the first multi-party elections are excluded from the analysis bringing the total number of elections in the 65 authoritarian countries in my sample to 190 .

\section{Dependent Variables}

Incumbent defeat: This variable, also based on NELDA, is a dummy variable that is coded as 1 if the party associated with the incumbent loses the election. In legislative elections, the variable is coded as 1 if the party associated with the incumbent in the executive loses the election. In my data, the opposition has managed to defeat the incumbent in 32 out of 190 elections (16.84\%).

Liberalizing Electoral Outcome: A liberalizing electoral outcome (LEO) is defined in terms of improvement in the competitiveness of elections or political rights, regardless of whether the improvement entails the installation of minimally democratic 
institutions - in other words, a democratic transition. Following Howard and Roessler (2006), the dummy LEO variable is coded when there is a three-point or greater increase in Polity IV and there is one-point or greater decrease in Freedom House political liberty score. By this measure, there are $18(9.5 \%)$ LEOs in my analysis. ${ }^{2}$

Democratic Transition: I present a second measure for democratization to ensure my finding is not reliant on a single measure of this complex concept. Consistent with Roessler and Howard (2009), a transition to electoral democracy is marked if a country goes over a score of six on the Polity IV scale, which indicates a democratic system, or dips below a score of two according to Freedom House, which signifies a country that enjoys a wide range of political rights such as fair and free elections. According to this measure, there are 21 democratic transitions in 190 elections (11.05\%).

These two measures of democratization do not overlap perfectly. There are seven LEOs in the analysis that are not identified as democratic transitions as they do not cross the threshold. Conversely, ten democratic transitions are not identified as LEO due to being identified by only Polity IV or Freedom House, or due to an increase of fewer than three points on the Polity IV index. As mentioned earlier, democratization may occur either through incumbent defeat or through incumbent victory in a free and fair election. In terms of this distinction, there are 7 LEOs without incumbent defeat (3.7\%), 11 LEOs with incumbent upset (5.82\%), and 21 incumbent defeats without LEO (11.11\%).

Similarly, there are 11 transitions with incumbent upset (5.79\%), 10 transitions without incumbent defeat (5.26\%), 20 elections with incumbent defeat in the absence of democratic transition (10.53\%), and 154 elections with no change (80.62\%).

\section{Independent Variable}


The independent variable for a particular election year in a single country is the cumulative count of protest events during the 365 days prior to the election. Data for the independent variable comes from the daily count of protest events in WHIV, the World Handbook IV of Political Indicators (Jenkins et al. 2012). WHIV is a refined version of contentious events from King and Lowe's (2003) “10 Million Dyadic Events,” which are computer-coded events from Reuters' newsfeed. This original dataset has been used by social scientists to study various phenomena such as influence of human rights INGOs (Murdie and Davis 2012), neo-liberal policy reform (Zelner, Henisz, and Holburn 2009), and anti-government protest in democracies (Su 2015). WHIV has improved upon the original data in several ways. Most importantly, the event count decreased by about $14.4 \%$ when events previously coded by the computer as contentious were identified to actually be non-contentious. The WHIV data has been also checked both internally against a basecode and externally by comparing with other events datasets. ${ }^{3}$ An additional advantage of the WHIV data is the ability to separate protests into before- and after-election categories, whereas annual data such as New York Times annual counts does not allow for such precision. Since this detailed WHIV data only covers 1990-2004, I limit my analysis to this period.

My analysis considers the effect of different forms of protest on democratic outcomes. All forms of protest except sit-ins had positive and statistically significant effects on the electoral outcome. I then counted the occurrence of all forms of protestprotest demonstration, picketing, damaging property, sit-ins and rioting ${ }^{4}$-to construct the total count for protest events, which totals 1,444 events in the 365 days before each of the 190 elections. These events are not necessarily political protests targeting the election 
since, as it was argued in the literature review, political grievances in authoritarian contexts are not often clearly expressed in direct political terms in addition to the potential of non-political demands quickly escalating to political claims.

While both incredibly detailed and comprehensive, the WHIV data has its own limitations. For example, the innovative use of concerts and posters for protest activities are not coded in this dataset. Also, the "everyday forms of resistance" or "nonmovements" that are more common in authoritarian settings (see Bayat 2010; Scott 1987) are not reflected in this dataset. The WHIV data does, however, provide good coverage of conventional protest tactics, or what is called the "modular repertoire" of contention (Tarrow 2011). Another limitation of the WHIV data is its lack of information on the size of protest events. However, from what we know about these elections, it seems that larger waves of protest are associated with larger numbers of events. For example, the Indonesian 1999 election witnessed the highest number of protest events, which reflects the massive protests and riots in Indonesia during 1998-9. Following Indonesia, the Albania 1997, Serbia 2000, and Russia 1993 elections show the highest frequency of contentious action. This quantitative ranking is supported by qualitative accounts of these countries documenting massive pre-election mobilization.

A straightforward bivariate analysis suggests a relationship between pre-election protests and election outcomes. The average protest count for elections without incumbent defeat is 5.83 compared to an average of 16.31 protest events preceding elections in which incumbents are defeated. The mean number of mobilization events before elections without LEO is 6.48 , while the average count of events before elections with LEO is 17.83 . Finally, the average number of contentious events before elections 
with no transition is 6.21 compared to a mean of 17.83 protests before elections with democratic transitions (Figure 1).

\section{Control Variables}

This analysis includes a series of control variables to address potential endogeneity problems as well as account for the following rival explanations: regime type, election type, socioeconomic context, international linkage, regime flexibility, regime electoral tactics, international pressure, and opposition electoral tactics.

First, I include a dummy variable to distinguish between competitive and hegemonic authoritarian regimes. In hegemonic authoritarian regimes, elections are held but repression and limitations on the opposition and voters are so severe that there is little uncertainty about the outcome. In competitive authoritarian regimes, opposition groups may compete for access to executive power through institutional channels. In such regimes, however, incumbents' abuse of state resources undermines the fairness of elections, violates civil liberties critical to election results, and renders the electoral playfield uneven (Howard and Roessler 2006; Levitsky and Way 2010). Cross-national analyses of these two regime types have suggested that competitive authoritarian regimes are more likely to experience a transition to electoral democracy compared to hegemonic and closed authoritarian regimes (Brownlee 2009a; Roessler and Howard 2009). Following Brownlee (2009b), this variable is constructed based on two indexes of legislative and electoral competitiveness from the World Bank's Database of Political Institutions (Beck et al. 2001). An autocratic regime is coded as competitive if the dominant party won less than $75 \%$ of the vote in the previous election. Including this 
variable addresses a rival explanation according to which the level of competition allowed by the regime drives both the election outcome and a high level of protest.

[Table 1 about here]

I also include a dummy variable to distinguish main elections, in which the executive is contested, from other elections. Presidential elections in presidential systems and legislative elections in parliamentary systems are main elections. There is also a variable indicating whether the incumbent is running in the election since absence of the incumbent in the election could be interpreted as a sign of regime weakness, which in turn may increase protest activity and the chance of opposition victory.

Scholars have also debated whether the level of economic development influences the probability of democratic transitions (Boix and Stokes 2003; Lipset 1994; Przeworski and Limongi 1997). One might argue that in countries with higher levels of economic development, the opposition would have a better chance at winning because citizens would have more resources for organizing protests. Accordingly, my analysis includes measures from the World Bank to control for GDP per capita (World Bank 2012). The variable is logged and one year lagged. Similarly, one could argue that poor economic performance affects the incumbent's ability to win the election and creates grievances related to economic adversity that encourage protest. Thus, I include a control variable for the percent of GDP growth from the World Bank to address both economic rival explanations.

Scholarship on oil-producing countries suggests that authoritarian regimes with access to oil are more resilient in face of the opposition challenges because oil revenues enable these regimes to build a strong security apparatus and pay off dissenters (Ross 
2001, 2012). Accordingly, one could expect a lower likelihood of opposition victory in oil-producing authoritarian countries as well as lower rates of protest activities (Smith 2004). Accordingly, the model includes a the logged version of oil production per capita in US dollars from Ross (2012).

Another rival explanation emphasizes that countries in Eastern and Central Europe and Latin America have strong linkages with Western powers that play critical roles in their electoral dynamics (Levitsky and Way 2010). In this context, linkage is defined as the density of economic, political, diplomatic, social, and organizational ties as well as cross-border flows of capital, goods, services, people, and information between a given country and democratic superpowers United States and the European Union. One could also hypothesize that a strong connection with Western powers would make protestors more hopeful about the possibility of foreign support and eventual success. Thus, I include dummy variables for countries in Central and Eastern Europe and Latin America.

Another rival explanation suggests that it might be the internal dynamics of a given political regime that encourage or discourage protest activities and subsequently determine the electoral outcomes. To address this alternative explanation, I follow Howard and Roessler (2006) in using the mean of each country's Freedom House Civil Liberties Score in the $\mathrm{X}$ years prior to the election as a measure for regime openness. I also include a variable indicating the change in the Political Rights Score in the four years before the election, which controls for the extent to which a process of liberalization—or deliberalization—is underway. 
My analysis also includes three dummy variables that measure the regime's tactics in each specific election. One variable from NELDA reports whether the regime harassed the opposition before the election. A second variable from NELDA indicates whether there was bias in the media coverage favoring the regime prior to the election. Finally, a variable based on NELDA and an additional dataset of annual "Human Rights Practices" reports from the U.S. State Department (Kelley and Kolev 2010) denotes whether the government committed fraud on election day.

In addition to regime tactics, two variables account for international factors affecting each election. One dummy variable drawn from NELDA indicates the presence of international monitors at the election. Another variable, international conditionality, borrowed from Donno (2013) indicates whether Western powers and prominent international organizations ${ }^{5}$ made promises or posed threats conditional on the quality of the election during the four months leading up to the election. Both of these variables address a rival explanation according to which both the election outcome and protest activities are driven by international pressure.

Finally, we should also take into account the electoral tactics of the opposition. One might argue that, rather than contentious collective action, it is the opposition's noncontentious mobilization that affects election outcomes. For instance, studies of democratization in electoral autocracies argue that there is a higher chance of democratization resulting from the election when the opposition forms a coalition. It might also be hypothesized that when the opposition is united, other contenders are more inclined to resort to protest activities. From Donno (2013), I include a dummy variable that accounts for whether opposition parties formed a unified platform, coordinated their 
campaign, or united behind a presidential candidate (see Table 1 for a statistical summary).

Method: The unit of analysis in this study is a single election in a particular authoritarian electoral regime. Incumbent defeat and democratization are analytically separate, albeit related, concepts that both have binary outcomes: the result of each election might be incumbent defeat or no incumbent defeat, democratization or the status quo. Thus, I first use logistic regression models to estimate the covariates of each outcome separately in keeping with previous studies of authoritarian elections (Donno 2013; Hafner-Burton, Hyde, and Jablonski 2014; Howard and Roessler 2006).

Nonetheless, while incumbent defeat and democratization are conceptually separate, they also overlap. Elections may result in democratization alongside incumbent defeat, democratization in the absence of incumbent defeat, or incumbent defeat without democratization. Estimating the effect of covariates on these outcomes in a single multinomial logistic regression, I test whether there is a relationship between pre-election protest and incumbent defeat as a pathway to democratic transition. To adjust for dependencies across elections within a country, I use robust standard errors clustered by country.

\section{Analysis}

Table 2 presents the results for the effects of covariates on the probability of incumbent defeat. Models 1 and 2 show that pre-election contention has a statistically significant positive effect on incumbent defeat net of all control variables. In other words, an increase in the number of pre-election protests is associated with an increase in the 
odds of incumbent defeat. This finding supports the hypothesis of this paper concerning the positive effect of pre-election mobilization on incumbent defeat. Among the control variables, only the covariate for opposition coalition is statistically significant: when the opposition is unified, the probability of incumbent defeat rises.

[Table 2 about here]

To interpret these results, I estimate changes in the predicted probability of the dependent variable under different conditions. That is, given our data and estimated model, I present the change in probability of the outcome of incumbent defeat occurring if we artificially shifted one key independent variable from a low value to a high value while leaving all other variables at their observed values. Accordingly, an increase from 0 to the median of 2 pre-election protests is associated with an $8.5 \%$ increase in probability of incumbent defeat. An increase to 7 protests $\left(75^{\text {th }}\right.$ percentile) results in a $32.17 \%$ boost in the probability of incumbent defeat compared to no protests before the election. Finally, moving from 0 to 27 events ( $95^{\text {th }}$ percentile) increases the probability of incumbent failure 2.62 times.

Table 3 presents the estimates for the effects of the covariates on the probability of an LEO and democratic transition. The covariate for pre-election contention is statistically significant and positive across all four models. An increase in the count of protest events is associated with an increase in the likelihood of a LEO or democratic transition. In Model 2, I have not included the variable for international monitors because it perfectly predicts the outcome and drops 47 observations. Nonetheless, even when we include that variable in the model the coefficient for pre-election protest is significant. Among the control variables other than opposition coalition, the covariate for 
main election is statistically significant across all models meaning the chance for an LEO in legislative elections in parliamentary systems and executive elections in presidential systems is higher compared to other elections.

[Table 3 here]

Table 4 presents the result of analysis for electoral outcome as a categorical variable with four possible outcomes: LEO without incumbent defeat, LEO with incumbent defeat, incumbent defeat without a LEO, and status quo as the omitted category. The outcome of LEO with incumbent defeat is most relevant to evaluating this paper's hypothesis, namely that pre-election protest increases the chance of incumbent defeat and, accordingly, democratization. The results indicate that pre-election contention has a positive and statistically significant effect on that outcome in support of my hypothesis. This finding is replicated when we treat democratic transition as a categorical variable with four possible outcomes: democratic transition without incumbent defeat, democratic transition with incumbent defeat, incumbent defeat without a democratic transition, and the omitted category of status quo. The coefficient for preelection contention is also statistically significant and positively associated with the possibility of democratic transition with incumbent defeat. This result affirms the main hypothesis of the paper and demonstrates that this finding - that pre-electoral protest in electoral authoritarianism is positively associated with subsequent democratic breakthroughs - is robust to different measures of democratization ${ }^{6}$.

[Table 4 about here]

Keeping all variables at their observed values, an increase from 0 to the median number of 3 protests increases the probability of LEO through incumbent defeat by 
$19.78 \%$. An increase to $9\left(75^{\text {th }}\right.$ percentile) is associated with $65.74 \%$ boost in the predicted probability of transition with incumbent upset. Finally, an increase to 31 protests $\left(95^{\text {th }}\right.$ percentile) raises the chance of a democratic transition through incumbent defeat 4.1 times.

This paper's main finding is also robust to different specifications of the models. Additional control variables such as measures for global integration, dummy and continuous variables for time, and the size of the military were entered in all models to ensure the results were not sensitive to the inclusion of these factors. Furthermore, as another measure for democratization, I combined the scores from Polity IV and Freedom House's Political Rights scores to create a continuous measure of democratization as an outcome of pre-election protest in a fixed effects regression model. ${ }^{7}$ The findings remained substantively unchanged.

\section{Discussion and Conclusion}

While elections in authoritarian countries often function as a mechanism for incumbents to consolidate their power, on some occasions a democratic breakthrough is achieved when incumbents lose at the ballot box. The effects of pre-election mobilization on electoral outcomes in authoritarian settings has not been adequately addressed in existing studies.

The extant literature on democratic transitions via elections has suggested two pathways for achieving a democratic transition. First, a transition could occur when the incumbent loses the election and power passes to the opposition. Second, a democratic transition could be achieved when the incumbent wins an election that is considered fair and free. I have argued that pre-election protest has an effect on election outcomes 
because it signals the viability of an alternative to the current order and illustrates the breadth of grievances to regime allies, opposition, and voters, which motivates elite defection and encourages voters to cast ballots for the opposition. I empirically tested this hypothesis by examining the effects of pre-election protest on incumbent defeat and democratization in 190 elections across 65 authoritarian regimes between 1990 and 2004. I find that the greater the number of protest events that occurred before an election, the more likely it was that the opposition defeated the authoritarian incumbent. It was also more likely to observe democratization in elections following an increased in protest activity. Treating the electoral outcome as a categorical variable, I found that the preelection protest is positively associated with democratization through incumbent defeat. This finding is consistent with previous findings in the literature on the positive effect of protest on democratization via elections (Howard and Roessler 2006; Schedler 2013). Still, my analysis is novel in several respects. First, by dividing democratization into democratization with and without incumbent defeat, my analysis achieves more specificity concerning which outcomes are affected by mobilization. Second, the paper expands the concept of protest and demonstrates that protest by diverse social groups, rather than just by the established political opposition, matters for election results. Third, by using a daily measure of protest, the paper demonstrates the effect of protest without conflating the effect of pre-and post-election contention.

Even though this study is an improvement on existing research on this topic, the data used in this analysis still has certain limitations. The data do not specifically identify which actors organized the protest, making it impossible to distinguish the electoral effects of protests organized by political parties from those organized by other civic 
organizations or from more spontaneous events. As cross-national datasets on protest events are improved and refined, future research might be able to provide answers to such questions.

The paper also makes several important contribution to the study of social movements and democratization. First, with its focus on the relationship between elections and protest, this paper acts as a bridge between the largely disconnected literatures on electoral studies and contentious politics. Second, the finding theorizes and documents the positive effect of unarmed protest in the process of democratization, which confirms recent scholarship on the effectiveness of nonviolent campaigns. Finally, the paper extends the scholarship on the outcome of social movements beyond industrialized democracies and highlights consequences other than policy change. Here, it is hoped that the paper encourages scholars of social movements to focus on institutional settings outside consolidated democracies, and to theorize movement effects in the context of those different institutions rather than trying to replicate theoretical models developed based on outcomes of policy change in mature Western democracies ${ }^{8}$.

More practically, this paper suggests that pro-democracy activists should focus their efforts on pre-election campaigns for competitive multiparty elections using contentious collective action. Using protest tactics could be as important as utilizing noncontentious electoral tactics such as coalition building and using post-election protest tactics to reverse the outcome of fraudulent elections.

\footnotetext{
${ }^{1}$ For more information, see http://hyde.research.yale.edu/nelda/.

${ }^{2}$ There were originally LEOs present in 20 out of 191 elections, but 2 of these were for elections held within a few days to one month of each other. In these two cases, I dropped the legislative election from the analysis to avoid over-counting LEOs. However, the major finding does not change even if these two elections are included.

${ }^{3}$ For more information, see http://sociology.osu.edu/worldhandbook.
} 


\footnotetext{
${ }^{4}$ These protest events all belong to the category of unarmed protest. This dataset does not provide a good account of armed protest events. As a result, it is not possible to compare the effect of armed and unarmed pre-election campaigns.

${ }^{5}$ Following Donno (2013), my analysis considers the following Western powers and important international organizations: the United States, United Nations, European Union (EU), Organization for Security and Cooperation in Europe (OSCE), Council of Europe, Organization of American States (OAS), Caribbean Community (CARICOM), Southern African Development Community (SADC), Economic Community of West African States (ECOWAS), and African Union.

6 The output is available from the author upon request

${ }^{7}$ The detailed results of the robustness tests are available from the author upon request.

8 This suggestion is in line with Amenta (2014) discussion of recent directions for studies of social movement outcome, and his recommendation for an institutioncentered approach.
} 


\section{Bibliography}

Acemoglu, Daren and James A. Robinson. 2005. Economic Origins of Dictatorship and Democracy. Cambridge University Press.

Almeida, Paul D. 2003. "Opportunity Organizations and Threat-Induced Contention: Protest Waves in Authoritarian Settings." American Journal of Sociology 109(2):345-400.

Amenta, Edwin. 2006. When Movements Matter: The Townsend Plan and the Rise of Social Security. Princeton University Press.

Amenta, Edwin. 2014. "How to Analyze the Influence of Movements." Contemporary Sociology: A Journal of Reviews 43(1):16-29.

Amenta, Edwin, Neal Caren, Elizabeth Chiarello, and Yang Su. 2010. "The Political Consequences of Social Movements." Annual Review of Sociology 36:287-307.

Andrews, Kenneth T. 2004. Freedom Is a Constant Struggle: The Mississippi Civil Rights Movement and Its Legacy. University of Chicago Press Chicago, IL.

Aspinall, Edward. 2005. Opposing Suharto: Compromise, Resistance, and Regime Change in Indonesia. Stanford, Calif.: Stanford University Press.

Banks, Arthur S. and Kenneth A. Wilson. 2013. Cross-National Time-Series Data Archive. Jerusalem, Israel: Databanks International.

Bayat, Asef. 2010. Life as Politics: How Ordinary People Change the Middle East. Amsterdam; Manchester: Amsterdam University Press.

Beck, Thorsten, George Clarke, Alberto Groff, Philip Keefer, and Patrick Walsh. 2001. "New Tools in Comparative Political Economy: The Database of Political Institutions." The World Bank Economic Review 15(1):165-76.

Beissinger, Mark R. 2002. Nationalist Mobilization and the Collapse of the Soviet State. Cambridge ;New York: Cambridge University Press.

Beissinger, Mark R. 2007. "Structure and Example in Modular Political Phenomena: The Diffusion of Bulldozer/Rose/Orange/Tulip Revolutions." Perspectives on Politics 5(2):259.

Bird, Judith. 1999. “Indonesia in 1998: The Pot Boils Over.” Asian Survey 39(1):2737.

Blaydes, Lisa. 2010. Elections and Distributive Politics in Mubarak's Egypt. New York: Cambridge University Press. 
Boix, Carles and Susan C. Stokes. 2003. "Endogenous Democratization." World Politics 55(4):517-49.

Boudreau, Vincent. 2009. Resisting Dictatorship: Repression and Protest in Southeast Asia. Cambridge: Cambridge Univeristy Press.

Brownlee, Jason. 2009a. "Harbinger of Democracy: Competitive Elections before the End of Authoritarianism." Democratization by Elections: A New Mode of Transition.

Brownlee, Jason. 2009b. "Portents of Pluralism: How Hybrid Regimes Affect Democratic Transitions." American Journal of Political Science 53(3):515532.

Bunce, Valerie and Sharon L. Wolchik. 2011. Defeating Authoritarian Leaders in Postcommunist Countries. Cambridge: Cambridge University Press.

Chenoweth, Erica and Maria J. Stephan. 2012. Why Civil Resistance Works: The Strategic Logic of Nonviolent Conflict. Reprint. Columbia University Press.

Diamond, Larry Jay. 2002. "Thinking about Hybrid Regimes.” Journal of Democracy 13(2):21-35.

Donno, Daniela. 2013. "Elections and Democratization in Authoritarian Regimes." American Journal of Political Science no-no.

Fallon, Kathleen M., Liam Swiss, and Jocelyn Viterna. 2012. "Resolving the Democracy Paradox Democratization and Women's Legislative Representation in Developing Nations, 1975 to 2009." American Sociological Review 77(3):380-408.

Giugni, Marco. 2007. "Useless Protest? A Time-Series Analysis of the Policy Outcomes of Ecology, Antinuclear, and Peace Movements in the United States, 1977-1995." Mobilization: An International Quarterly 12(1):53-77.

Giugni, Marco G. 1998. "Was It Worth the Effort? The Outcomes and Consequences of Social Movements." Annual Review of Sociology 24:371-93.

Goldstone, Jack A. 2003. States, Parties, and Social Movements. Cambridge University Press.

Goodwin, Jeff. 2001. No Other Way Out; State and Revolutionary Movements, 19451991. Cambridge: Cambridge University Press.

Hafner-Burton, Emilie M., Susan D. Hyde, and Ryan S. Jablonski. 2014. "When Do Governments Resort to Election Violence?" British Journal of Political Science $4(1): 149-79$. 
Haggard, Stephan and Robert R. Kaufman. 1995. The Political Economy of Democratic Transitions. Princeton University Press.

Haggard, Stephan and Robert R. Kaufman. 2012. "Inequality and Regime Change: Democratic Transitions and the Stability of Democratic Rule." American Political Science Review 106(3):495-516.

Hmed, Choukri. 2012. "Réseaux Dormants, Contingence et Structures." Revue Française de Science Politique 62(5):797.

Howard, Marc Morjé and Philip G. Roessler. 2006. "Liberalizing Electoral Outcomes in Competitive Authoritarian Regimes." American Journal of Political Science 50(2):365-381.

Huntington, Samuel P. 1984. “Will More Countries Become Democratic?" Political Science Quarterly 99(2):193-218.

Hyde, Susan D. and Nikolay Marinov. 2012. "Which Elections Can Be Lost?" Political Analysis 20(2):191-210.

Jenkins, J.Craig, Charles Lewis Taylor, Marianne Abbott, Thomas V. Maher, and Lindsey Peterson. 2012. The World Handbook of Political Indicators IV. Columbus, OH: Mershon Center for International Security Studies, The Ohio State University. Retrieved September 25, 2013 (https://sociology.osu.edu/worldhandbook).

Kelley, Judith G. and Kiril Kolev. 2010. Election Quality and International Observation 1975-2004: Two New Datasets. Rochester, NY: Social Science Research Network. Retrieved November 12, 2014 (http://papers.ssrn.com/abstract=1694654).

King, Gary and Will Lowe. 2003. "10 Million International Dyadic Events." IQSS Dataverse Network.

Kuran, Timur. 1995. Private Truths, Public Lies: The Social Consequences of Preference Falsification. Cambridge, Mass.: Harvard University Press.

Kurzman, Charles. 2004. The Unthinkable Revolution in Iran. Cambridge, Mass.: Harvard University Press.

Levitsky, Steven and Lucan Way. 2002. "The Rise of Competitive Authoritarianism." Journal of Democracy 13(2):51-65.

Levitsky, Steven and Lucan Way. 2010. Competitive Authoritarianism: Hybrid Regimes after the Cold War. New York: Cambridge University Press. 
Lijphart, Arend. 2012. Patterns of Democracy: Government Forms and Performance in Thirty-Six Countries. Yale University Press.

Lipset, Seymour Martin. 1994. "The Social Requisites of Democracy Revisited: 1993 Presidential Address." American Sociological Review 59(1):1-22.

Lust-Okar, Ellen. 2006. "Elections under Authoritarianism: Preliminary Lessons from Jordan." Democratization 13(3):456-71.

Magaloni, Beatriz. 2008. "Credible Power-Sharing and the Longevity of Authoritarian Rule.” Comparative Political Studies 41(4-5):715-41.

Marshall, Monty, Ted Gurr, and Keith Jaggers. 2011. "Polity IV Project. Polity Regime Characteristics and Transitions, 1800-2010. User's Manual." Center for Systemic Peace (Http://www. Systemicpeace. org/inscr/p4manualv2009).

McAdam, Doug and Sidney Tarrow. 2010. "Ballots and Barricades: On the Reciprocal Relationship between Elections and Social Movements." Perspectives on Politics 8(2):529-542.

McAdam, Doug, Sidney G. Tarrow, and Charles Tilly. 2001. Dynamics of Contention. Cambridge ; New York: Cambridge University Press.

Meyers, Nancy L. 2009. “Vreme Je! It's Time! Mobilization and Voting for Regime Change, the Serbian Elections of 2000." THE GEORGE WASHINGTON UNIVERSITY. Retrieved October 21, 2014 (http://gradworks.umi.com.libproxy.lib.unc.edu/33/66/3366454.html).

Murdie, Amanda M. and David R. Davis. 2012. "Shaming and Blaming: Using Events Data to Assess the Impact of Human Rights INGOs1." International Studies Quarterly 56(1):1-16.

Norris, Pippa. 2004. Electoral Engineering: Voting Rules and Political Behavior. Cambridge University Press.

O'Donnell, Guillermo and Philippe C. Schmitter. 1986. Transitions from Authoritarian Rule, Vol. 4: Tentative Conclusions about Uncertain Democracies. The Johns Hopkins University Press.

Oliver, Pamela. 1989. "Bringing the Crowd Back in: The Nonorganizational Elements of Social Movements." Research in Social Movements, Conflict and Change 11:1-30.

Pasuk, Phongpaichit and Chris Baker. 2002. Thailand: Economy and Politics. 2 edition. Oxford ; New York: Oxford University Press. 
Pop-Eleches, Grigore and Graeme B. Robertson. 2015. "Information, Elections, and Political Change." Comparative Politics 47(4):459-95.

Przeworski, Adam and Fernando Limongi. 1997. "Modernization: Theories and Facts." World Politics 49(2):155-83.

Roessler, Philip G. and Marc M. Howard. 2009. "Post-Cold War Political Regimes: When Do Elections Matter?" Democratization by Elections 101-27.

Ross, Michael L. 2001. “Does Oil Hinder Democracy?” World Politics 53(3):325-61.

Ross, Michael L. 2012. The Oil Curse: How Petroleum Wealth Shapes the Development of Nations. Princeton University Press.

Saidani, Mounir. 2012. "Revolution and Counterrevolution in Tunisia: The Forty Days That Shook the Country." Boundary 2 39(1):43-54.

Schedler, Andreas, ed. 2006. Electoral Authoritarianism: The Dynamics of Unfree Competition. Lynne Rienner Pub.

Schedler, Andreas. 2009. "Sources of Competition under Electoral Authoritarianism." Pp. 179-201 in Democratization by election: A new mode of transition, edited by S. I. Lindberg.

Schedler, Andreas. 2013. The Politics of Uncertainty: Sustaining and Subverting Electoral Authoritarianism. Oxford: Oxford University Press.

Schock, Kurt. 2005. Unarmed Insurrections: People Power Movements in Nondemocracies. Minneapolis: University of Minnesota Press.

Scott, James C. 1987. Weapons of the Weak: Everyday Forms of Peasant Resistance. Reprint edition. New Haven: Yale University Press.

Smith, Benjamin. 2004. "Oil Wealth and Regime Survival in the Developing World, 1960-1999." American Journal of Political Science 48(2):232-246.

Snow, David A., Sarah A. Soule, and Hanspeter Kriesi. 2008. The Blackwell Companion to Social Movements. Wiley-Blackwell.

Su, Yen-Pin. 2015. "Anti-Government Protests in Democracies: A Test of Institutional Explanations." Comparative Politics 47(2):149-67.

Tarrow, Sidney. 2012. Strangers at the Gates: Movements and States in Contentious Politics. 1st ed. Cambridge University Press.

Tarrow, Sidney G. 2011. Power in Movement: Social Movements and Contentious Politics. Cambridge University Press. 
Tilly, Charles and Sidney G. Tarrow. 2007. Contentious Politics. Paradigm Publishers Boulder, CO.

Tucker, Joshua A. 2007. "Enough! Electoral Fraud, Collective Action Problems, and Post-Communist Colored Revolutions." Perspectives on Politics 5(3):535.

Wejnert, Barbara. 2005. "Diffusion, Development, and Democracy, 1800-1999." American Sociological Review 70(1):53-81.

Wood, Elisabeth Jean. 2000. Forging Democracy from Below: Insurgent Transitions in South Africa and El Salvador. Cambridge University Press.

World Bank. 2012. World Development Indicators 2012. Washington, D.C.: World Bank.

Zelner, Bennet A., Witold J. Henisz, and Guy L. F. Holburn. 2009. “Contentious Implementation and Retrenchment in Neoliberal Policy Reform: The Global Electric Power Industry, 1989-2001." Administrative Science Quarterly 54(3):379-412. 